\title{
"Large Ocean States": Sovereignty, Small Islands, and Marine Protected Areas in Global Oceans Governance
}

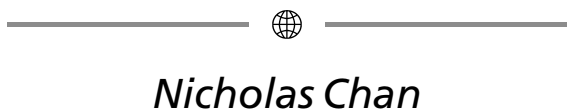

Small island states are typically portrayed as vulnerable and insignificant actors in international affairs. This article traces the emerging selfidentification of "large ocean states" that these small island states in the Pacific and Indian Oceans are now employing, juxtaposing their miniscule landmass and populations with the possession of sovereign authority over large swathes of the world's oceans. Such authority is increasingly being exercised in the context of biodiversity conservation through expanding marine protected areas (an element of both the Sustainable Development Goals and the Aichi Targets of the Convention on Biological Diversity) as an expression of "ecological responsibility." This new exercise of green sovereignty reinforces state control over spaces previously governed only at a distance, but control made possible only through compromises with nonstate actors to fund, monitor, and govern these MPAs. KEYWORDs: biodiversity, sovereignty, global governance.

IN SEPTEMBER 2016, ADDRESSING THE ANNUAL CONGRESS OF THE INTERNATIONAL Union for the Conservation of Nature (IUCN), Tommy E. Remengesau Jr., president of Palau, declared his country not to be a "small island state," as might be the conventional description for a country of 25,000 people and a land area of only $500 \mathrm{~km}^{2}$, but a "large ocean state."1 The chief justification for doing so was the establishment the previous year of the Palau National Marine Sanctuary (PNMS), designating 80 percent of Palau's exclusive economic zone (EEZ) of $600,000 \mathrm{~km}^{2}$ as a "no-take zone" entirely closed to fishing activities - an area the size of California and the sixth-largest marine protected area (MPA) in the world. The remaining 20 percent of Palau's EEZ would be limited to domestic fishing only, barring foreign fleets in the service of marine protection and biodiversity conservation. ${ }^{2}$

Remengesau's declaration of a "large ocean state" and the establishment of the PNMS were but one recent reminder that considerable parts of the world's oceans and living resources are under the jurisdiction of erstwhile small island states with tiny populations and landmasses. In recent years, the language of the "large ocean state" has increasingly been employed by the leaders of various Pacific and Indian Ocean states, as a counterpoint to the usual "small state" 
nomenclature. For example, Tony de Brum, late foreign minister of the Marshall Islands said, "The Marshall Islands covers an area of approximately a million square miles of ocean. Many people call us a small island state. I prefer to be called a large ocean state." 3 The term large ocean state has also been deployed in UN General Assembly debates (by Anote Tong, former president of Kiribati) and even as the theme of a regional meeting (at the 2012 Pacific Islands Forum summit, hosted by the Cook Islands, under the banner of "Large Ocean Island States"). ${ }^{4}$ Meanwhile, the first-ever UN Ocean Conference, hosted in June 2017 in New York City, marks the newfound political attention that oceans protection is receiving, especially in the context of the Sustainable Development Goals.

In this article, I explore the distinctive contribution that small island states are making to this emerging oceans agenda, particularly in the way that sovereign authority and control of the state are being reasserted through efforts at global environmental protection. Small islands have traditionally been portrayed as weak states, lacking elements of positive sovereignty. Through rethinking their own smallness as instead being large ocean states, however, these states are engaged in constructing a new sovereignty bargain, echoing earlier arguments surrounding the "greening of sovereignty" in world politics. ${ }^{5}$ Small island states have played a pivotal role in the recent trend within global oceans governance of creating large marine protected areas (LMPAs), encompassing hundreds of thousands of square kilometers of ocean, as called for by Sustainable Development Goal 14 on marine conservation. As a term that has received only passing academic attention, ${ }^{6}$ in this article I consider the implications of the rethinking of identity and expression of sovereignty through the large ocean state, particularly as an indicator of new forms of governance emerging over the world's ocean spaces.

I begin this article by providing an overview of the emerging political attention to oceans conservation, and the significance of LMPAs in global oceans governance. Next, I turn to how the large ocean state discourse challenges conventional understandings of smallness in international politics. Then, I explore the dynamics through which LMPA creation and large ocean state discourse provide new opportunities for a reassertion of sovereign authority and control by small islands through these efforts at greening sovereignty. Finally, I demonstrate three examples of these dynamics through countries at the forefront of articulating large ocean state discourse as well as LMPA creation: Kiribati, Palau, and the Seychelles.

\section{The Biodiversity Crisis, Oceans Conservation, and Large Marine Protected Areas}

Oceans conservation is now on the global political agenda, with a rapidly escalating awareness of the crisis of health of marine ecosystems and pelagic species. At the UN Ocean Conference in June 2017, governments declared that "we are committed to halting and reversing the decline in the health and productivity 
of our ocean and its ecosystems and to protecting and restoring its resilience and ecological integrity." This "ocean agenda" encompasses a range of issues: marine pollution, including plastic pollution; fishery management and subsidies; adaptation to climate change impacts; and scientific research and public education, among other things.

One indicator of this agenda has been the emergence of a specific policy practice: to expand the area of the ocean covered by marine protected areas. ${ }^{8}$ The past decade has seen a dramatic increase in the global maritime protected area, from 2.35 million $\mathrm{km}^{2}$ in 2006 to at least 14.2 million $\mathrm{km}^{2}$ by $2014 .{ }^{9}$ This increase in the coverage of MPAs has been associated with political convergence over the desirability of such growth in MPAs. The 2010 Convention on Biological Diversity conference, in agreeing on the Aichi Biodiversity Targets, called for "at least" 10 percent of coastal and marine areas to be conserved through protected areas and area-based conservation measures by $2020 .{ }^{10}$

This 10 percent target was subsequently reaffirmed in the adoption of the 2015 Sustainable Development Goals as part of Goal 14 to "conserve and sustainably use the oceans, seas and marine resources for sustainable development." 11 Recent estimates suggest that the international community is now more than twothirds of the way to this 10 percent target. ${ }^{12}$ Much of this progress, however, has been the result of the emergence of a particular approach to marine conservationthe creation and establishment of large marine protected areas that encompass hundreds of thousands of square kilometers in often uninhabited ocean spaces, as opposed to the previous trend of marine protected area establishment in coastal and shallow-water habitats. ${ }^{13}$

The commitment of Aichi Target 11 provides an incentive for this emerging trend since, without LMPAs, the goal would be achieved only by mid-century based on current progress. Substantively, marine scientists have argued that the protection of marine habitats at scale is also necessary to protect entire ecosystems, habitats far from the shore (i.e., seamounts), and migratory species (including those that may shift as a result of climate change) and to avoid fragmentation in protected area management. ${ }^{14}$ While this practice is not without criticism - for instance, over the biodiversity representativeness of areas where MPAs are created, the size of the no-take zone where fishing activities are completely closed, and the implications for indigenous peoples and coastal communities of such closure - the trend of LMPA creation looks set to stay. ${ }^{15}$

The first LMPAs created from the 1970s onward, as well as many of the more recent LMPAs, were established by large Western states - mainly, the United States, the United Kingdom, France, and Australia. ${ }^{16}$ These states still account for the majority of global MPA protection, especially through their overseas territories, with the United States, the United Kingdom, and Australia alone making up over 50 percent of the global oceans covered by MPAs. These efforts at LMPA creation, however, have now also been joined by small island states, encompassing a substantial proportion of their EEZs, with the world's then largest MPA-Marae 
Moana, comprising 1.97 million $\mathrm{km}^{2}$ - formally established by the Cook Islands in July $2017 .{ }^{17}$ For these small island states, however, compared to large Western states, LMPA creation has signified more radical changes in their sovereign practices and expression of national identities, which I detail in the next section.

\section{Rethinking Sovereignty: From Small States to Large Oceans}

Small states have, in recent years, been the subject of increasing attention in international relations. The general starting point for this scholarship lies in an observation about their vulnerability: that smallness (variously defined) begets a precarious vulnerable position (variously defined) in world politics, but that there are also differing reactions and responses to this vulnerability. ${ }^{18}$ This is particularly true in the case of small island states, where research has highlighted the particular economic and governance challenges arising from being a small island: the tyranny of distance, reliance on air and sea transport for the movement of goods and people, the existential challenges posed by climate change, and so forth.

As a result of these concerns, special treatment for small island states has been established in many international forums and processes, with the institutionalization of the "small island developing state" (SIDS) nomenclature in international politics. For instance, the UN system's decadal conferences dedicated to SIDS and a high representative (shared with landlocked developing countries and Least Developed Countries) are intended to ensure that the specific concerns of SIDS are properly addressed within the UN's agenda. ${ }^{19}$ Despite the structural disadvantages arising from size, the creative agency of small island states in international affairs has therefore also been a key theme in this scholarship. Small island states have been described as exercising "moral leadership," and possessing the ability to "borrow" power and play an outsized role in international diplomacy on climate change, both in shaping the direction of the climate regime and in achieving differentiated treatment for themselves..$^{20}$ As Jon Barnett and John Campbell note, however, these institutional incentives and access to preferential treatment also provide small states with reason to emphasize their own smallness and their own vulnerability. ${ }^{21}$

In contrast to these emphases on vulnerability, the emergence of the large ocean state discourse is especially notable because it challenges and rejects the physical feature of smallness that underpins the small (island) state scholarship. Instead, this emerging discourse returns in part to a realist conception of power in international politics: that (material) size matters in international politics and that territorial size is a form of power. The articulation of being a "large ocean state" reminds neighbors and conventionally large states of their sovereign rights under the legal regime established through the 1982 UN Convention on the Law of the Sea (UNCLOS): while full sovereignty applies to the 12-nautical-mile zone of the territorial sea, as recognized by Article 2, coastal states are also accorded an 
exclusive economic zone of up to 200 nautical miles from their coastlines under Article 56, with "sovereign rights for the purpose of exploring and exploiting, conserving and managing the natural resources." 22 As a result, tiny islands dispersed over wide ocean spaces expand the marine territory of a state many times over; the international legal maritime regime thus provides quasi-territorial rights over a considerable proportion of the world's oceans to a handful of small states. ${ }^{23}$ As Table 1 indicates, the largest EEZ-to-landmass states are mostly small island developing states..$^{24}$ Indeed, as the ongoing claims over the extended continental shelf (that would extend sovereign rights over nonliving resources beyond the EEZ) are reviewed by the UNCLOS Commission on the Limits of the Continental Shelf, the ocean spaces to which coastal states' sovereign rights apply are likely to increase further yet. ${ }^{25}$

Table 1 Top Fifteen States with Largest Marine to Land Area Ratios

\begin{tabular}{lrrrrr}
\hline Name & $\begin{array}{c}\text { Marine Area } \\
\left(\mathrm{km}^{2}\right)\end{array}$ & $\begin{array}{c}\text { Marine } \\
\text { Protected } \\
\text { Area }(\%)\end{array}$ & $\begin{array}{r}\text { Land } \\
\text { Area } \\
\left(\mathrm{km}^{2}\right)\end{array}$ & $\begin{array}{c}\text { Land } \\
\text { Protected } \\
\text { Area (\%) }\end{array}$ & $\begin{array}{c}\text { Mand Area } \\
\text { Ratio }\end{array}$ \\
\hline Tuvalu & $731,900.0$ & 0.01 & 41.8 & 2.39 & 17,510 \\
Cook Islands & $1,972,842.4$ & 100.00 & 258.1 & 25.99 & 7,644 \\
Marshall Islands & $2,004,587.3$ & 0.27 & 281.9 & 11.92 & 7,111 \\
Federated States of Micronesia & $3,011,917.0$ & 0.02 & 817.2 & 0.05 & 3,686 \\
Kiribati & $3,459,130.4$ & 11.82 & $1,032.6$ & 22.37 & 3,350 \\
Maldives & $922,110.0$ & 0.05 & 304.7 & 1.21 & 3,026 \\
Seychelles & $1,340,839.5$ & 0.04 & 486.9 & 42.10 & 2,754 \\
Palau & $608,152.5$ & 82.99 & 501.1 & 27.94 & 1,214 \\
Niue & $318,243.7$ & 0.01 & 267.8 & 19.96 & 1,188 \\
Tonga & $668,054.6$ & 1.51 & 766.5 & 15.92 & 872 \\
Mauritius & $1,280,068.3$ & 0.00 & $2,062.5$ & 4.75 & 623 \\
Barbados & $185,019.8$ & 0.01 & 444.1 & 1.27 & 417 \\
Antigua and Barbuda & $108,492.4$ & 0.16 & 455.2 & 18.67 & 238 \\
Monaco & 284.2 & 99.93 & 1.6 & 33.16 & 178 \\
Malta & $55,696.7$ & 6.27 & 325.0 & 30.29 & 171 \\
\hline
\end{tabular}

Source: UN Environment Programme World Conservation Monitoring Centre (UNEPWCMC), "Global Statistics from the World Database on Protected Areas (WDPA)" (Cambridge, UK: UNEP-WCMC, March 2018).

This claim about ocean largeness, however, is qualified by observing the challenges that small island states encounter in exercising full sovereign control over their EEZs, unlike Western states. Scholarship on sovereignty and developing countries, particularly small and weak states, has long recognized the gap between the authority of a state to act and control its territory, and its actual ability to do so. Most notably, Robert Jackson's quasi-state approach distinguishes between "negative" sovereignty, where states possess juridical statehood and legal recognition, and "positive" sovereignty, where empirical statehood (or the ability to effectively control territory) is not fully established. ${ }^{26}$ In the modern era, negative sovereignty and legal recognition over territory is not in question, includ- 
ing the principle of EEZ rights, notwithstanding some disputes over their exact demarcation. ${ }^{27}$ Small states - islands or otherwise - have little fear of conquest. And as Tom Long observes, "It is a good time in history to be a small state." 28

It is in regard to their positive sovereignty, however, where small states face their greatest challenges in international politics. While a variety of strategies have been employed by small states to not just survive but thrive, ${ }^{29}$ in the context of the marine environment small island states have faced this challenge of exercising positive sovereignty, especially over their ability to police, guard, and enforce control over their EEZs. The UNCLOS regime's recognition of EEZ rights includes exclusive authority over fishing (or more generally, "living resources"), which coastal states have typically sought to exploit through the licensing of fishing vessels, foreign or domestic, to access and operate within their EEZs. ${ }^{30}$ While such licensing and access fees are major sources - if not the major source — of national income for many small island states, they also have long struggled to properly regulate and control fishing activity in their waters and the problem of illegal, unreported, and unregulated (IUU) fishing, especially from distant water fleets. ${ }^{31}$ Limited coast guard fleets and other limited enforcement capabilities have meant that fish stock overexploitation has intensified. Various measures, such as shiprider agreements (allowing enforcement officers to travel on foreign vessels to patrol the EEZ) or more recently the 2009 Food and Agriculture Organization (FAO) Port States Agreement, partially but not completely mitigate the monitoring and enforcement challenge over vast EEZs. The regulation of fishing activity in EEZs (with a complete prohibition, or no-take regulation, at one end of the spectrum) that MPA creation entails therefore faces the same challenges of positive sovereignty that island states have confronted ever since UNCLOS established sovereign rights in EEZs.

The "large ocean state" description in this way is therefore an attempt by small island states to reassert and reclaim positive sovereignty over their ocean EEZs. The articulation of the "large ocean state," however, can be seen as not just a physical and material categorization, but as a normative and subjective one that also distinguishes island states and their LMPA creation from those of large Western states. The large ocean state, in other words, rethinks smallness as a form of identity. As Donna Lee and Nicola J. Smith point out, the "language of smallness sets the contours of what is politically and economically possible and what is not. The discourse of smallness provides the language of opportunity and constraint within which small states are situated in the international political economy." 32

Rejecting the label of "smallness" therefore-as the common juxtaposition that "we are not a small island state but instead are a large ocean state" indicates - is arguably a rejection of the self-identification of vulnerability that state smallness has come to be associated with. Instead, it also expresses a different "language of opportunity and constraint" for these states to be not just legally responsible for the health of the large tracts of ocean that constitute their EEZs, 
but morally responsible too. And small island states are choosing to exercise this responsibility through the practice of LMPA creation within national EEZs.

\section{The Greening of Sovereignty in Marine Protected Areas}

The main argument I advance in this article, therefore, is that positive sovereignty is being realized - not necessarily in a completely new way, but certainly to a greater degree than has hitherto been the case for small island states - through the practice of LMPA creation. The articulation of "large ocean state" identity has resulted in the corresponding notion that small island states need to realize positive sovereignty in EEZs to substantively (and not just rhetorically) be large ocean states. Enhancing sovereign control in EEZs to establish effective LMPAs is therefore a form of greening sovereignty, but it also ultimately serves the broader political objective of securing positive sovereignty in international politics.

In comparison to developed countries for which LMPA creation is accompanied by requisite resources, the resource limitations of small states have thus far limited monitoring and enforcement capabilities over these large EEZs with regard to fishing access rights, as noted above. The same is conceivably true for the implementation of marine protection plans, resulting in the criticism and warning that these LMPAs may simply be "paper parks," existing on paper but with limited substantive changes in practice. ${ }^{33}$ For instance, Palau's establishment of the PNMS was preceded by the establishment of a shark sanctuary in 2009 which, Elizabeth M. De Santo argues, saw no substantial change to efforts or capabilities at marine monitoring. ${ }^{34}$

In response to the paper park criticism, a key feature of the new LMPAs being implemented by large ocean states lies in how sovereign control and practice is being reconfigured. States are having to devise and implement a range of practices over their EEZs to maximize the effectiveness of LMPAs - inter alia, to monitor incursions by unauthorized fishing vessels, pursue and interdict violators, and prosecute and punish those guilty of fishing within LMPAs. Additionally, new remote sensing, satellite-based, and drone technologies, allowing poachers and unauthorized intruders to LMPAs to be detected at a distance, contribute toward increasing control over EEZs and bringing "an end to the era of marine anonymity." ${ }^{35}$ All of these practices, in other words, serve to enhance positive sovereignty of states over their EEZs. As James Scott might have put it, these technologies help states to "see" remote spaces previously outside the effective reach and governance of the state ${ }^{36}$ and, as Karen Litfin has previously recognized, they "prepare a given territory for the exercise of sovereignty." 37

Such exercises of sovereignty within EEZs are also legally unilateral ones, as Bernard H. Oxman observes, reflecting the "territorial temptation" of coastal states to expand sovereign control for environmental ends. ${ }^{38}$ While on the one 
hand, the domestic political priority accorded to LMPAs has served to allocate limited state resources to meet these ends, states have not been left to their own devices. These enhancements of positive sovereignty are not purely unilateral ones and have also crucially been enabled by the increased involvement of nonstate actors in advocating for and implementing LMPAs. The result is a form of private-public environmental governance, often labeled as "partnerships." 39 As Justin Alger and Peter Dauvergne highlight, environmental nongovernmental organizations (NGOs) have been "central players in the emergence of the large MPA norm. $"{ }^{40}$ Financial contributions from large conservation-oriented NGOs and private foundations and trusts, such as Conservation International (CI) and The Nature Conservancy (TNC), have been important sources of funding for the drive to designate LMPAs - for instance, through helping to bear management costs or offset lost income from fishing access fees. These efforts are particularly significant in the context of donor fatigue and a competitive development aid environment where LMPA creation and claims to oceans protection provide one way for states to compete and highlight their attractiveness to wealthy prospective partners to secure external financial or technological assistance.

Furthermore, civil society actors often are also engaged in the governance of the LMPAs themselves, although the form of involvement varies. ${ }^{41}$ Some forms of the new technologies mentioned above are owned or managed by nonstate actors, rather than being directly controlled by and under state authority. For instance, the Pew Charitable Trusts' Project Eyes on the Seas uses satellite imagery, vessel databases, and automated analysis to detect suspicious fishing activity to create a "virtual watch room" and monitor the oceans from afar. ${ }^{42}$ Thus, while only state authority can formally and legally enclose ocean spaces, the ability of the state to do so and achieve control has required the development of a new relationship between state and nonstate actors.

The engagement of nonstate actors in these partnerships that enhance sovereign control has also been complemented by diplomatic efforts to raise oceans to prominence on the global political agenda. The inclusion of Sustainable Development Goal 14 as a stand-alone goal was one focus of these efforts, ${ }^{43}$ as was the creation of a new UN special envoy for the ocean following the 2017 UN Ocean Conference. As large ocean states seek to secure the necessary resources and build the partnerships to achieve effective LMPA implementation, the development of the international oceans agenda is likely to proceed apace.

The broader significance of this emerging practice, finally, also suggests the development of a new form of thinking about the purpose of sovereign authority and control. The establishment of the UNCLOS regime and EEZ rights originally provided optimism that the enclosure of fisheries under the sovereign authority of a single state would contribute to greater conservation of fish stocks. Instead, the opposite seems to have been the case, where states - island states among themhave sought to exploit the rents from their formalized property rights, leading to 
escalating concern over overfishing that has prompted the LMPA norm. ${ }^{44}$ The new measures described in this section that serve to enhance sovereignty and state control can arguably work for both environmentally beneficial and detrimental ends. Addressing IUU fishing does not necessarily mean that fishing quotas or catch levels are set sustainably; increasing access to areas far from shore can also open them up to other forms of economic exploitation such as deep seabed mining.

It is therefore potentially significant that LMPA creation has been accompanied by a new moral claim about "ecological responsibility," emphasizing not the rights to extract but a norm of stewardship and environmental protection. While the robustness of this norm is something to be examined and is not yet taken for granted, the normative emphasis on responsibility at least provides reason to think that efforts at LMPA creation will be more durable than previous optimism about the greening of sovereignty. ${ }^{45}$ In this way, the emergence of the large ocean state provides at least one response to Robert Falkner's question of "what it means to be a modern nation-state in an age of ecological constraints." 46

\section{Three Large Ocean States: Kiribati, Palau, and the Seychelles}

The sovereign bargain that is emerging with the creation of LMPAs and the large ocean state discourse, then, illustrates how small states that have often struggled to achieve positive sovereignty via control over their ocean territory are actually affording themselves greater such sovereign control through their entrepreneurial role in advancing global norms on sovereignty and biodiversity protection. In this section, I illustrate these dynamics of positive sovereignty and large ocean state identity through three examples from the Pacific and Indian Ocean contexts where this identity has been most prominently expressed and sovereign control is being visibly enhanced.

\section{Kiribati's Phoenix Islands Protected Area}

Following the first comprehensive scientific surveys in the early 2000s that highlighted the richness of its marine life, ${ }^{47}$ the Phoenix Islands Protected Area (PIPA) was declared by Kiribati in 2006 and established in 2008, the first substantial large MPA designated by a developing country. ${ }^{48}$ Its area spans $400,000 \mathrm{~km}^{2}$, encompassing 11 percent of Kiribati's 3.5 million $\mathrm{km}^{2} \mathrm{EEZ}$, compared to its land area of just $800 \mathrm{~km}^{2}$. Its no-take zone initially encompassed 4 percent of the MPA, but the entire zone has been declared closed to commercial fishing since 2015 . Kiribati's former president Tong, who left office in 2016, has been one of the most prominent heads of state to articulate large ocean state language, citing and justifying this claim through the example of the PIPA. ${ }^{49}$

Addressing a European Union-African, Caribbean and Pacific Group of States (EU-ACP) meeting in 2015, President Tong explained the motivations for establishing the MPA: 
It is not just about the economics of fisheries, it is also about taking full responsibility as part of this global community. As a small island but large ocean state, and as part of our obligation to preserve such a resource, Kiribati closed off more than 400,000 square kilometres of its EEZ - the Phoenix Islands Protected Area - or commonly known as PIPA, from all forms of fisheries extraction .... The closing of PIPA has not been smooth sailing, but as a government, we considered that this is a necessary sacrifice and contribution for the good of mankind. ${ }^{50}$

Tong's statement, in particular its emphasis on responsibility, underscores the connection between LMPA creation as a normative expression of ecological responsibility understood within the context of large ocean state identity that its EEZ provides. Since Tong's retirement, the notion of Kiribati as a large ocean state is one that has continued to be employed by public officials, suggesting the durability of this identity conception in Kiribati's self-image. ${ }^{51}$

The sovereignty bargain in which Kiribati engages thus has seen the full closure of the PIPA to commercial fishing, and Kiribati uses its sovereign authority to exclude foreign fishing vessels from the MPA zone. However, the PIPA experience also demonstrates the new forms of governance that have been necessary to implement the MPA and is cited as an example of a buyout conservation strategy. ${ }^{52}$ Recognizing the forgone income from fishing licensing fees,${ }^{53}$ the Kiribati government, together with two nonstate partners - CI and the New England Aquarium — established the PIPA Trust Fund, with a joint initial endowment of $\$ 5$ million by the government and CI. ${ }^{54}$ The fund provides resources for the implementation and management of the PIPA — but also "may provide the Government with reasonable compensation for loss of revenue occasioned by measures to limit or prohibit exploitation of the resources," serviced through a "conservation contract" entered into by the government and the trust fund that "buys" the economic value of the MPA for conservation purposes. ${ }^{55}$

Legislation passed by the Kiribati legislature notes that "the Board of the Trust [Fund] will not make any decisions about the content of the management plan (which remains the sovereign responsibility of the Government)," instead simply determining "how best it can support the implementation of the plan." 56 Nonetheless, the trade-off replaces fishing revenue previously directly accruing to and overseen by the government with an alternative financial source that is jointly managed and disbursed by the government and these two nonstate actors.

\section{Palau's National Marine Sanctuary}

The Palau National Marine Sanctuary Act was passed by the Palau National Congress in 2015, encompassing Palau's entire EEZ and designating 80 percent of this (beyond nearshore areas) as a no-take zone. The sanctuary follows previous initiatives - the 2009 designation of the world's first shark sanctuary and the reinvigoration of a cultural notion of marine conservation called the bul. 
As in the other examples, the initiative has required the development of nonstate and state partnerships to access resources beyond national budgets; in this case, primarily with the Pew Charitable Trusts, through its Global Ocean Legacy project that seeks to "create 15 great parks in the sea-all at least 200,000 square kilometres-by 2022." 57

While preparations to implement the sanctuary are ongoing and envisaged to be effective by 2020 , a notable aspect of this effort thus far has been a concerted effort to improve Palau's ability to monitor and enforce the sanctuary through actions to enhance state control over its EEZ. A new "Monitoring, Control and Surveillance" strategy sets out a range of measures to be implemented in the coming years: training and increasing the number of marine enforcement officers and support personnel; developing detention and prison facilities to detain intruders into the EEZ as, on occasion, fishermen violating the zone have had to be released due to insufficient jail capacity; improving technological capabilities for real-time communication; developing air surveillance patrols; and expanding radar capabilities. ${ }^{58}$ Under these plans, which also rely on the cooperation of regional state and nonstate partners, new institutional structures for interagency coordination will have to be established, and staffing and personnel will have to increase.

Palau's offshore coast guard fleet of one was doubled by a 40-meter-long patrol boat donated by two Japanese groups, the Sasakawa Peace and Nippon Foundations, ${ }^{59}$ illustrating the participation of NGOs (including foreign NGOs) in enhancing Palau's sovereign control. At the February 2018 handover ceremony of this new boat, Palau's vice president Raynold Oiluch declared that support from these foundations meant that Palau now had "one of the most state of the art surveillance and enforcement operations in the entire [Pacific] region." ${ }^{\circ 6}$ Finally, the strategy also calls for building a runway and ship refueling facilities on Helen Reef - a group of uninhabited islands some 300 nautical miles south of the main archipelago, currently accessible only by boat and which the strategy acknowledges is "largely uncontrolled"-further extending the effective control of the state over its territory and waters. ${ }^{61}$

In short, Palau's move to close off the vast majority of its EEZ to fishing through the creation of the sanctuary promises to extend the sovereign control of the state over its waters in ways that were previously unattainable. Ensuring that this LMPA avoids the paper park criticism to achieve improved marine biodiversity thus necessarily requires the state to truly become a large ocean state that can control what happens not just on its islands, but also on its waters.

\section{The Seychelles's Marine Spatial Planning Exercise}

Leaders of the Indian Ocean island archipelago of the Seychelles have been some of the most prominent utilizers of large ocean state language. Its former president, James Michel, for instance, said in 2015 that "we aspire to empower ourselves as large ocean states — as "blue guardians. " ${ }^{62}$ Similarly, Finance Minister Jean-Paul 
Adam juxtaposes the small island state with the large ocean state, "Seychelles-a small island developing state in terms of land territory, but a large ocean state when we factor in our vast ocean space," and UN Permanent Representative Ronny Jumeau also is one of the rhetorical entrepreneurs of the large ocean state. ${ }^{63}$

In February 2018, the Seychelles announced the designation of its first two LMPAs, the Aldabra Group and Amirantes to Fortune Bank areas, which together amount to $210,000 \mathrm{~km}^{2} .{ }^{64}$ These two LMPAs constitute 16 percent of its 1.3 million $\mathrm{km}^{2} \mathrm{EEZ}$, but are part of a broader commitment to designate 30 percent of its EEZ by 2020, heralding the future designation of at least another $190,000 \mathrm{~km}^{2}$ of protected waters. ${ }^{65}$ The significance of this plan, however, is that these LMPAs are the result of a debt-for-nature swap with the Seychelles's Paris Club creditors, an example of the innovative financing mechanisms and partnerships under way in governing marine conservation in these ocean spaces. Like the other examples cited above, this $\$ 21.6$ million debt buyback arrangement involved significant nonstate and private sector involvement in financing and implementation: a low-interest loan from global NGO The Nature Conservancy, and \$5 million in grants from the Leonardo DiCaprio Foundation and other private foundations and trusts. ${ }^{66}$ These will be channeled to a new body, the Seychelles Conservation and Climate Adaptation Trust, governed by a board of government officials and local stakeholders, including a TNC representative. The trust is responsible for overseeing the completion of a marine spatial plan by 2020 , including the designation of MPAs and the location of no-take zones within these MPAs, and is expected to contribute $\$ 600,000$ annually to marine conservation activities. ${ }^{67}$

While the Seychelles's LMPA creation is thus only at an initial stage, its claim to marine responsibility that the large ocean state discourse embodies has enabled it to engage its creditors to reach an agreement that ultimately improves the state's overall economic position and attracts private support for conservation objectives. Like many other small states, the Seychelles had faced a debt crisis over the past decade - including default in 2008, and the need for International Monetary Fund assistance and reform programs - putting development objectives into question. ${ }^{68}$ While progress in debt sustainability had been made since 2008, the Finance Ministry notes that the debt-for-nature swap will "smooth out the repayment profile of Seychelles's official bilateral debt, whilst increasing the proportion of debt that can be serviced in local currency," ${ }^{69}$ freeing up foreign exchange for other purposes.

Meanwhile, the marine spatial planning exercise - led by TNC staff-that the debt swap enables also serves to increase state control over the Seychelles's marine resources. As Environment Minister Didier Dogley observes, the objective of this planning process is to serve the Seychelles's "effective utilisation of our ocean space" 70 to ultimately make visible, manage, and govern what it has always had authority over, but hitherto has not fully seen. 


\section{Conclusion}

The rapid and recent expansion of large marine protected areas by small island states has seen these states recast their identities from small island states to large ocean states. The emerging discourse and self-identification of the large ocean state reflects the new sovereign bargain that these states are engaging in to assert sovereign control over their EEZs in the context of global biodiversity conservation and oceans protection. The challenge of protecting increasing proportions of the world's oceans, as called for by Aichi Target 11 and Sustainable Development Goal 14, makes some of the world's smallest states key actors in this global conservation effort. Crucially, it provides them with the opportunity to increase state control through the argument that doing so contributes to the greening of sovereignty. Such control is also being enhanced through deep partnerships with nonstate actors over the design, financing, and implementation of these LMPAs. These partnerships, at the same time, also raise questions of accountability, power, and the politics of these new forms of governing the world's oceans at the level of the individual LMPA and the global norm of LMPA creation..$^{71}$ Nonetheless, even as concerns intensify about the potential sovereign implications of sea-level rise to some of these same states, ${ }^{72}$ their activity in advancing LMPA creation demonstrates the continuing entrepreneurship and creative agency of small states in global governance - not only in contributing to global conservation norms, but also in how these norms serve broader political goals of securing positive sovereignty.

At the same time, what has changed little in recent years is the expanse of oceans conserved outside the reach of national sovereignties - the "high seas," or marine biodiversity of areas beyond national jurisdiction (BBNJ). Just 1.18 percent of the high seas (themselves 61 percent of the ocean surface area) are covered by MPAs, even after the 2 million $\mathrm{km}^{2}$ Ross Sea MPA entered into force in December $2017 .{ }^{73}$ The high seas also are areas, however, where effective protection in the global commons that has yet to be "sovereignized"74 will require a different form of sovereign bargain than those enacted within EEZs. Compared to the relatively neat sovereign authority that the EEZ regime provides, MPA creation in the high seas is complicated by institutional mandates and legal authority that is distributed over a fragmented complex of existing institutions and principles. ${ }^{75}$ Nonetheless, progress in the decade-long negotiations toward a new UNCLOS international legally binding agreement on BBNJ (where MPAs are one of four key themes) recommended in July 2017 that the UN General Assembly begin formal intergovernmental negotiations. ${ }^{76}$ The success of these efforts at oceans conservation, however, will face new challenges, norms, and modes of governance being developed outside of national EEZs. With millions of square kilometers of oceans expected to be protected in coming years - existing MPA pledges are already estimated at over 15 million $\mathrm{km}^{2}$ - further understanding the changing politics of marine protection and global oceans governance remains a vital step for the success of effectively protecting the world's oceans. ${ }^{77}$ 


\section{Notes}

Nicholas Chan is lecturer in global studies at the School of Arts and Social Sciences, Monash University Malaysia. His research focuses on developing country participation in global environmental governance, and he has published in the journals Ethics and International Affairs and the Review of European, Comparative, and International Environmental Law.

1. International Union for Conservation of Nature (IUCN) World Conservation Congress, "Our Joint Battle Has Just Begun," 1 September 2016, www .iucnworldconservationcongress.org/news/20160901/article/our-joint-battle-has-just -begun, accessed 5 July 2017.

2. Republic of Palau, "Palau National Marine Sanctuary Act," Senate Bill 9-30, SD-2, HD-3, 22 October 2015, http://palaugov.pw/wp-content/uploads/2015/10/RPPL -No.-9-49-Palau-National-Marine-Sanctuary-Act.pdf.

3. Ari Shapiro, "For the Marshall Islands, the Climate Goal Is '1.5 to Stay Alive,', WBUR, 9 December 2015, www.wbur.org/npr/459053208/for-the-marshall-islands-the -climate-goal-is-1-5-to-stay-alive, accessed 5 July 2017.

4. Permanent Mission of Kiribati to the United Nations, "Statement by H.E. President Anote Tong, 69th UNGA,” 26 September 2014, www.un.org/en/ga/69/meetings/gadebate/ pdf/KI_en.pdf, accessed 5 July 2017; Pacific Islands Forum, "Forty-third Pacific Islands Forum: Forum Communique," 30 August 2012, www.ifrc.org/docs/IDRL/43rd\%20Pacific \%20Islands\%20Forum\%20Communique\%20-\%20FINAL.pdf, accessed 5 July 2017.

5. Karen Litfin, "The Greening of Sovereignty: An Introduction," in Karen Litfin, ed., The Greening of Sovereignty (Cambridge: MIT Press, 1998).

6. Nic Maclellan, "Transforming the Regional Architecture: New Players and Challenges for the Pacific Islands," Asia Pacific Issues, no. 118 (2015): 7. "Small Island States with LMPAs Become Large Ocean States with Globally Valued Resources"; Rebecca L. Gruby, Noella J. Gray, Lisa M. Campbell, and Leslie Action, "Towards a Social Science Research Agenda for Large Marine Protected Area," Conservation Letters 9, no. 3 (2016): 157.

7. UN General Assembly, Resolution 71/312: Our Ocean, Our Future: A Call for Action, UN Doc. A/RES/71/312 (14 July 2017).

8. Justin Alger and Peter Dauvergne, "The Global Norm of Large Marine Protected Areas: Explaining Variable Adoption and Implementation," Environmental Policy and Governance 27, no. 4 (2017): 298-310.

9. Lisa Boonzaier and Daniel Pauly, "Marine Protection Targets: An Updated Assessment of Global Progress," Oryx 50, no. 1 (2016): 32; Jane Lubchenco and Kirsten GrorudColvert, "Making Waves: The Science and Politics of Ocean Protection," Science 350, no. 6259 (2015): 382-383. For more up-to-date assessments, see protectedplanet.net/marine.

10. Convention on Biological Diversity, "Decision X/2: Strategic Plan for Biodiversity 2011-2020 and the Aichi Biodiversity Targets," UN Doc. UNEP/CBD/COP/DEC/X/2 (29 October 2010).

11. UN General Assembly, Resolution 70/1: Transforming Our World: The 2030 Agenda for Sustainable Development, UN Doc. A/RES/70/1 (21 October 2015), Goal 14.5.

12. UN Environment Programme World Conservation Monitoring Centre (UNEP- 
WCMC) and IUCN, "Protected Planet: Explore the World's Marine Protected Areas," https://protectedplanet.net/marine, accessed 6 December 2017.

13. Lisa M. Campbell, Noella J. Gray, Luke Fairbanks, Jennifer J. Silver, Rebecca L. Gruby, Bradford A. Dubnik, and Xavier Basurto, "Global Oceans Governance: New and Emerging Issues," Annual Review of Environment and Resources 41 (2016): 530531 , noting that a definition of a "large" MPA ranges from upwards of $30,000 \mathrm{~km}^{2}$ to $250,000 \mathrm{~km}^{2}$.

14. Robert J. Toonen, T. 'Aulani Wilhelm, Sara M. Maxwell, Daniel Wagner, Brian W. Bowen, Charles R.C. Sheppard, Sue M. Taei, et al., "One Size Does Not Fit All: The Emerging Frontier in Large-scale Marine Conservation," Marine Pollution Bulletin 77, nos. 1-2 (2013): 7-10; Graham Edgar, Rick D. Stuart-Smith, Trevor J. Willis, Stuart Kininmonth, Susan C. Baker, Stuart Banks, Neville S. Barrett, et al., "Global Conservation Outcomes Depend on Marine Protected Areas with Five Key Features," Nature 506, no. 7487 (2014): 216-220.

15. Nicholas K. Dulvy, "Super-sized MPAs and the Marginalization of Species Conservation," Aquatic Conservation: Marine and Freshwater Ecosystems 23, no. 3 (2013): 357-362; Pierre Leenhardt, Bertrand Cazalet, Bernard Salvat, Joachim Claudet, and Francois Feral, "The Rise of Large-scale Marine Protected Areas: Conservation or Geopolitics?" Ocean and Coastal Management 23, Part A (2013): 112-118; Rebecca L. Singleton and Callum M. Roberts, "The Contribution of Very Large Marine Protected Areas to Marine Conservation: Giant Leaps or Smoke and Mirrors?" Marine Pollution Bulletin 87, nos. 1-2 (2014): 7-10; P.J.S. Jones and E.M. De Santo, "Viewpoint-Is the Race for Remote, Very Large Marine Protected Areas (VLMPAs) Taking Us Down the Wrong Track?" Marine Policy 73 (2016): 231-234.

16. The Barack Obama administration was particularly active in MPA creation. See White House, "Fact Sheet: President Obama to Create the World's Largest Marine Protected Area," 26 August 2016, https://obamawhitehouse.archives.gov/the-press-office /2016/08/26/fact-sheet-president-obama-create-worlds-largest-marine-protected-area, accessed 7 September 2017.

17. Radio New Zealand, "Cook Islands Marae Moana Legislation Passed," 14 July 2017, www.radionz.co.nz/international/pacific-news/335067/cook-islands-marae -moana-legislation-passed.

18. Matthew Bishop, “The Political Economy of Small States: Enduring Vulnerability?" Review of International Political Economy 19, no. 5 (2012): 942-960; Jon Barnett and John Campbell, Climate Change and Small Island States (London: Routledge, 2010), pp. $155-167$.

19. Philippe Hein, "Small Island Developing States: Origin of the Category and Definition Issues," in UN Conference on Trade and Development, Is a Special Treatment of Small Island Developing States Possible? UN Doc. UNCTAD/LDC/2004/1 (New York: UN, 2004): 1-22.

20. Carola Betzold, “ 'Borrowing' Power to Influence International Negotiations: AOSIS in the Climate Change Regime, 1990-1997," Politics 30, no. 3 (2010): 131148; Nicole Deitelhoff and Linda Wallbott, "Beyond Soft Balancing: Small States and Coalition-building in the ICC and Climate Negotiations," Cambridge Review of International Affairs 25, no. 3 (2012): 345-366.

21. Barnett and Campbell, Climate Change and Small Island States, pp. 165-166. 
22. UN Convention on the Law of the Sea (UNCLOS), 10 December 1982, entered into force 16 November 1994, Part II: Territorial Sea and Contiguous Zone, and Part V: Exclusive Economic Zone.

23. Bernard H. Oxman, "The Territorial Temptation: A Siren Song at Sea," American Journal of International Law 100, no. 4 (2006): 830-851.

24. A similar calculation based on different sources also makes the same observation, that of the twenty largest states by "EEZ per capita," eighteen are SIDS. See Matthias Bruckner, "Effectively Addressing the Vulnerabilities and Development Needs of Small Island Developing States," Committee on Development Policy Background Paper No. 17, UN Doc. ST/ESA/2013/CDP/17 (New York City: CDP, 2013), p. 11.

25. Juan L. Suarez-de Vivero, "The Extended Continental Shelf: A Geographical Perspective of the Implementation of Article 76 of UNCLOS," Ocean and Coastal Management 73 (2013): 113-126.

26. Robert H. Jackson, Quasi-states: Sovereignty, International Relations, and the Third World (Cambridge: Cambridge University Press, 1993).

27. Mark W. Zacher, "The Territorial Integrity Norm: International Boundaries and the Use of Force," International Organization 55, no. 2 (2001): 215-250; J.C. Sharman, "Sovereignty at the Extremes: Micro-states in World Politics," Political Studies 65, no. 3 (2017): 559-575.

28. Tom Long, "Small States, Great Power? Gaining Influence Through Intrinsic, Derivative, and Collective Power," International Studies Review 19, no. 2 (2016): 185.

29. See also Naren Prasad, "Small but Smart: Small States in the Global System," in Andrew Cooper and Timothy Shaw, eds., The Diplomacies of Small States (Basingstoke: Palgrave, 2009): 41-64.

30. UNCLOS, Art. 61.

31. Rachel A. Schurman, "Tuna Dreams: Resource Nationalism and the Pacific Islands' Tuna Industry,” Development and Change 29, no. 1 (1998): 107-136; David Agnew, John Pearce, Ganapathiraju Pramod, Tom Peatman, Reg Watson, John R. Beddington, and Tony J. Pitcher, "Estimating the Worldwide Extent of Illegal Fishing," PLOS ONE 4, no. 2 (2009).

32. Donna Lee and Nicola J. Smith, "Small State Discourses in the International Political Economy,” Third World Quarterly 31, no. 7 (2010): 1095.

33. Campbell et al., "Global Oceans Governance," p. 530.

34. Elizabeth M. De Santo, "From Paper Parks to Private Conservation: The Role of NGOs in Adapting Marine Protected Area Strategies to Climate Change," Journal of International Wildlife Law and Policy 15, no. 1 (2012): 25-40.

35. For one example of such new observational technologies, Automated Ship Identification Systems (AIS), see Douglas J. McCauley, Paul Woods, Brian Sullivan, Bjorn Bergman, Caroline Jablonicky, Aaron Roan, Michael Hirschfield, Kristina Boerder, and Boris Worm, "Ending Hide and Seek at Sea," Science 351, no. 6278 (2016): 1150.

36. James C. Scott, Seeing Like a State (New Haven: Yale University Press, 1999).

37. Karen T. Litfin, "The Status of the Statistical State: Satellites and the Diffusion of Epistemic Sovereignty," Global Society 13, no. 1 (1999): 103.

38. Oxman, "The Territorial Temptation." 
39. On private environmental governance, see Liliana B. Andonova, "Public-Private Partnerships for the Earth: Politics and Patterns of Hybrid Authority in the Earth System," Global Environmental Politics 10, no. 2 (2010): 25-53.

40. Alger and Dauvergne, "The Global Norm of Large Marine Protected Areas," p. 301.

41. See a further discussion of the role of NGOs in MPAs in DeSanto, "From Paper Parks to Private Conservation."

42. Pew Charitable Trusts, "Project Eyes on the Seas," March 2015, www.pewtrusts .org/en/research-and-analysis/issue-briefs/2015/03/project-eyes-on-the-seas.

43. Genevieve Quirk and Quentin Hanich, "Ocean Diplomacy: The Pacific Islands' Countries Campaign to the UN for an Ocean Sustainable Development Goal," Asia-Pacific Journal of Ocean Law and Policy 1, no. 1 (2016): 68-95.

44. Oran Young, "The Role of Institutions in Causing and Confronting Environmental Problems," International Environmental Agreements 3, no. 4 (2003): 377-393.

45. Karen Litfin, "Sovereignty in World Ecopolitics," Mershon International Studies Review 41, no. 2 (1997): 194-196.

46. Robert Falkner, "Global Environmentalism and the Greening of International Society," International Affairs 88, no. 3 (2012): 520.

47. Peter Shelley, "Contracting for Conservation in the Central Pacific: An Overview of the Phoenix Islands Protected Area," Proceedings of the Annual Meeting (American Society of International Law) 106 (2012): 511-516.

48. Randi Rotjan, Regen Jamieson, Ben Carr, Les Kaufman, Sangeeta Mangubhai, David Obura, Ray Pierce, et al., "Establishment, Management, and Maintenance of the Phoenix Islands Protected Area," in Magnus L. Johnson and Jane Sandell, eds., Advances in Marine Biology, vol. 69 (Oxford: Academic Press, 2014): 289-324.

49. UN meetings coverage GA/11563, "Leaders Sound Alarm in General Assembly Debate on Unprecedented Mix of Challenges in Middle East, Taking 'Terror to a New Era and a New Level," " 26 September 2014, www.un.org/press/en/2014/ga11563.doc.htm, accessed 7 September 2017.

50. African, Caribbean and Pacific Group of States, "Statement by the President of the Republic of Kiribati H.E. Mr Anote Tong at the 29th Session of the ACP-EU Joint Parliamentary Assembly, 16 June 2015, Suva, Fiji," www.acp.int/content/statement-president -republic-kiribati-he-mr-anote-tong-29th-session-acp-eu-joint-parliamenta, accessed 7 September 2017.

51. Republic of Kiribati, "Statement by Hon. Minister Mr. Tebao Awerika, Minister of Environment, Lands and Agricultural Development, High-Level Segment, UNEA 2nd Meeting, Nairobi, Kenya, 23rd-27th May 2016," https://wedocs.unep.org/bitstream /handle/20.500.11822/17523/KIRIBATI\%20FINAL\%20STATEMENT\%20-\%20HLS docx.

52. Eduard Niesten, Heidi Gjersten, and Patrick S. Fong, "Incentives for Marine Conservation: Options for Small Island Developing States," Environment and Development Economics 18, no. 4 (2012): 440-458.

53. Around 35 percent of government revenue is estimated to come from fishing licensing fees, although this applies to all licensing from Kiribati and not just from the Phoenix Islands. See Shelley, "Contracting for Conservation in the Central Pacific."

54. Conservation International, "Phoenix Islands Protected Area," 2017, www 
.conservation.org/projects/pages/phoenix-islands-protected-area.aspx, accessed 7 September 2017.

55. Republic of Kiribati, "Phoenix Islands Protected Area Conservation Trust Act 2009," no. 1 of 2009, 8 May 2009. See also Phoenix Islands Protected Area, "Phoenix Islands Protected Area Conservation Trust," 2012, www.phoenixislands.org/trust.php, accessed 7 September 2017.

56. Republic of Kiribati, "Phoenix Islands Protected Area Conservation Trust Act 2009."

57. Pew Charitable Trusts, "Global Ocean Legacy_About," www.pewtrusts.org /en/archived-projects/global-ocean-legacy/about, accessed 24 August 2017. The Global Ocean Legacy was established in 2006 but in 2016 was superseded by a new initiative, the Pew Bertarelli Global Ocean Project.

58. Eric Terrill, Seth Horstmeyer, Keobel Sakuma, Richard Douglass, and Ellen Kappell, "The Republic of Palau Exclusive Economic Zone: Monitoring, Surveillance and Control: The Next Five Years, 2016-2021," Palau National Marine Sanctuary Office, 2015, http://palaugov.pw/wp-content/uploads/2016/05/palau_mcs_strategic_plan_final .pdf. See also Ian Urbina, "Palau vs. the Poachers,"New York Times, 17 February 2016 , www.nytimes.com/2016/02/21/magazine/palau-vs-the-poachers.html.

59. Yohei Sasakawa, "Speech: Meeting of Four Governments and Two NGOs for Enhancing Coast Guard Capabilities and Promoting Eco-conscious Tourism in the Republic of Palau," 26 February 2016, www.nippon-foundation.or.jp/en/who/message/speeches /2016/3.html.

60. Bernadette Carson, "New Japan Patrol Boat Boosts Palau Fight Against IUU," Pacific Note, 14 February 2018, www.pacificnote.com/single-post/2018/02/14/New -Japan-Patrol-Boat-boosts-Palau-fight-against-IUU.

61. Terrill et al., "The Republic of Palau Exclusive Economic Zone," p. 50.

62. Office of the President of the Republic of Seychelles, "President James Michel at the Forefront of Debate Promoting the Sustainability of Oceans on Clinton Global Initiative Panel," 20 September 2015, www.statehouse.gov.sc/news.php?news_id=2879, accessed 7 September 2017.

63. "World Oceans Day 2015- 'Our Oceans Are a Source of Life,'” The Nation, 8 June 2015, www.nation.sc/article.html?id=245660, accessed 7 September 2017; Department of Foreign Affairs, "Seychelles' Permanent Representative to the United Nations Presents Credentials to the UN Secretary-General," Department of Foreign Affairs of the Republic of the Seychelles, 11 May 2017,www.mfa.gov.sc/static.php?content_id=18\&news_id= 1437, accessed 7 September 2017.

64. Damian Carrington, "Debt for Dolphins: Seychelles Creates Huge Marine Parks in World-first Finance Scheme," The Guardian, 22 February 2018, www.theguardian.com /environment/2018/feb/22/debt-for-dolphins-seychelles-create-huge-new-marine-parks -in-world-first-finance-scheme.

65. Ministry of Environment, Energy and Climate Change, "Nomination of Aldabra Group as National Park and Amirantes to Fortune Bank as Area of Outstanding Natural Beauty," 8 November 2017, http://seymsp.com/wp-content/uploads/2018/01/SEYMSP Phase1_NominationPackage_8Nov2017.pdf.

66. Ministry of Finance, Trade and Economic Planning, "Seychelles Closes Landmark Buyback of Paris Club Debt and Activates Marine Conservation and Climate Change 
Adaptation Initiative," 4 March 2016, www.finance.gov.sc/press-releases/26/Seychelles -closes-landmark-buyback-of-paris-club-debt-and-activates-marine-conservation-and -climate-change-adaptation-initiative, accessed 7 September 2017.

67. Seychelles Marine Spatial Planning, "Fact Sheet," December 2015, http://seymsp .com/wp-content/uploads/2014/06/SEYMSP_FactSheet_A4_v4_17Mar2016.pdf, accessed 7 September 2017. See also "A New Plan to Protect the Water Around the Seychelles," The Economist, 7 September 2017.

68. Kaymara Bennett, Altricia Dawson, and Sidona McKenzie, "The Debt Experience of SIDS in the Atlantic, Indian Ocean, Mediterranean and South China Sea," in Damien King and David F. Tennant, eds., Debt and Development in Small Island Developing States (New York: Palgrave Macmillan, 2014), pp. 97-134; International Monetary Fund, "IMF Survey: Seychelles Marks Five Years of Successful Economic Transition," 20 December 2013, www.imf.org/en/News/Articles/2015/09/28/04/53/socar122013b, accessed 7 September 2017.

69. Ministry of Finance, Trade and Economic Planning, "Seychelles Closes Landmark Buyback of Paris Club Debt."

70. Didier Dogley, "We Are a Large Ocean State," in UN Development Programme (UNDP), Voices of Impact: Speaking for the Global Commons (New York: UNDP, 2016): 24-27.

71. Theresa Kramarz and Susan Park, "Introduction: The Politics of Environmental Accountability," Review of Policy Research 34, no. 1 (2017): 4-9.

72. Michael B. Gerrard and Gregory E. Wannier, eds., Threatened Island Nations: Legal Implications of Rising Seas and a Changing Climate (Cambridge: Cambridge University Press, 2013).

73. UNEP-WCMC and IUCN, "Protected Planet."

74. Litfin, "Sovereignty in World Ecopolitics," p. 184.

75. Natalie C. Ban, Tammy Davies, Stacy E. Aguilera, Cassandra Brooks, Michael Cox, Graham Epstein, Louisa S. Evans, Sara M. Maxwell, and Mateja Nenadovic, "Systemic Conservation Planning: A Better Recipe for Managing the High Seas for Biodiversity Conservation and Sustainable Use," Conservation Letters 7, no. 1 (2014): 82-91; Elisabeth Druel and Kristina M. Gjerde, "Sustaining Marine Life Beyond Boundaries: Options for an Implementing Agreement for Marine Biodiversity Beyond National Jurisdiction Under the United Nations Convention on the Law of the Sea," Marine Policy 49 (2014): 90-97.

76. UN, "Report of the Preparatory Committee Established by General Assembly Resolution 69/292: Development of an International Legally Binding Instrument Under the United Nations Convention on the Law of the Sea on the Conservation and Sustainable Use of Marine Biological Diversity of Areas Beyond National Jurisdiction" (advance unedited version), 21 July 2017, www.un.org/depts/los/biodiversity/prepcom_files/Procedural _report_of_BBNJ_PrepCom.pdf.

77. UNEP-WCMC and IUCN, "Protected Planet." 